\title{
College English Education Platform Based on Browser/Server Structure and Flipped Classroom
}

\author{
https://doi.org/10.3991/ijet.v14i15.11147 \\ Yuanbo Li, Chenhui Qu \\ Hebei Vocational College for Railway Transportation, Shijiazhuang, China \\ anthoney@ $163 . \mathrm{com}$
}

\begin{abstract}
The English proficiency of Chinese college students is mainly constrained by their low interest in English learning. The English educators in Chinese colleges must improve the initiative of their students to learn English. This paper attempts to create a college English teaching platform based on computer networking technology. Taking flipped classroom as the theoretical basis of college English education, the author introduced the concept and development of flipped classroom, and verified the feasibility of applying the theory in English teaching. To provide the media for flipped classroom, a college English teaching platform was built on the browser/server $(\mathrm{B} / \mathrm{S})$ structure, and used to promote the information-based English teaching in colleges. The functional modules and main interfaces of the platform were illustrated one by one. The flipped classroom-based B/S teaching platform was adopted for one semester by a college in Hunan Province. The class using this platform was taken as the test group, and another class without using the platform as the control group. The English scores of the two groups were compared, confirming the effectiveness of the proposed platform. Our research demonstrates the value of flipped classroom, and the proposed teaching platform helps improve the efficiency of college English teaching.
\end{abstract}

Keywords-Browser/server (B/S) structure, flipped classroom, college English teaching, teaching practice

\section{$1 \quad$ Introduction}

Today, China has improved its international status and influence year after year, Chinese culture and Chinese language have been more and more influential around the world, but in the foreseeable decades, English still dominates the international exchange, finance, trade, IT, computer technology, and other industries. It is still the focus of quality education in universities in China. English proficiency is still the basic skill of students to improve their capabilities and adaptability to work [1].

At the moment, the students' English level in China is still very low. There are some gaps in English education in universities such as low interest of students, single teaching model and lack of teaching interaction, etc. To improve the English education level, scholars in relevant industries have attempted to explore this area in various 
ways, for example, the application of computer multimedia technology in classroom teaching helps enrich English teaching content; corpus technology provides an indigenous application for students to learn English vocabulary; computer remote education platforms such as MOOCs, Netease open class, etc. have built diverse learning models [2]. A huge mass of English learning information and resources are already integrated in the Internet. However, there is currently lack of such an English education platform with theoretical guidance since it features openness, convenience and reliability, and if available, it can help students improve interest in learning English with high learning efficiency [3].

Based on the flipped classroom, this paper aims to design a high-quality teaching platform with easy access to the daily English teaching interaction for students. Underlain by the $\mathrm{B} / \mathrm{S}$ architecture, this platform is implemented using ASP.NET, a web programming tool, and SQL Server, a database support [4]. According to requirement analysis, it is designed for students' English education based on the flipped classroom to allow them to access different teaching and learning functions. In the application of college English teaching practice, the platform has been proven to be helpful in improving students' English level by the frontend and backend methods.

\section{$2 \quad$ Flipped Classroom}

\subsection{Concept and features}

With an aim of stimulating students' interests in learning English, Flipped classroom allows the most part of the traditional education that originally happen in the classroom to be preceded in pre-class phase to let students absorb relevant English knowledge after class, that is, the stress is lain on perceptions and learning of knowledge points before class, and on digestion and absorption of them in class [5]. The integration of flipped classroom into English teaching practice requires more computer aided teaching for easy communication and discussion between teachers and students and between student groups with learning platform. The schematic diagram of the flipped classroom is shown in Fig 1.

Flipped classroom has three features: 1. realize the regression from the passive learning of students in the traditional classroom to the autonomic learning model, improve their negative attitude towards learning and intrigue their interests in learning; 2. based on computer-aided teaching models, extremely enrich teaching resources and make it possible to implement multiple carrier English learning model. 3. integrate multiple teaching methods to teach students at different levels according to their aptitude in the situation, and achieve the goal of hierarchical diversified teaching [6]. This model was originated based on a variety of foreign learning theories and applied in the United States. Till now, it has been fruitful in experimental study of foreign language education and acquisition [7], feasible in the students' English education in China. In the implementation phase, it focuses on the actual situation of the students and selects the learning materials with comprehensive knowledge and that accord with students' cognition. In addition, the teachers still have to play a leading role in the 
flipped classroom, and should gain an insight into the performances of students before class and in class, discover their inadequacies and underline the difficult details of English knowledge. Flipped classroom can cultivate students' English learning competence at different dimensions and levels. It should have a composite evaluation on several fronts.

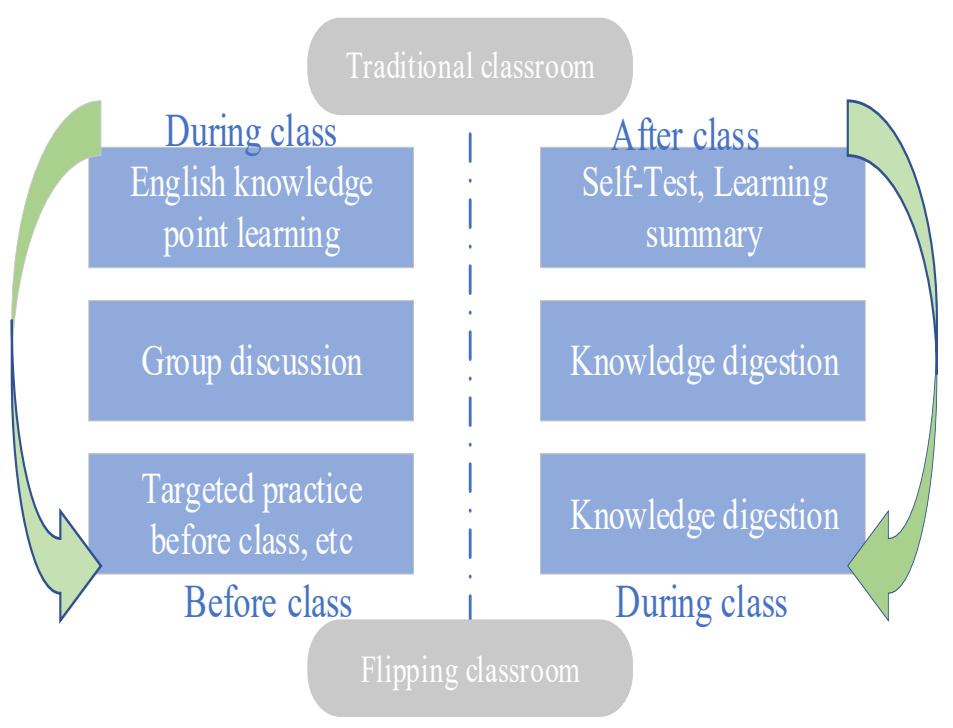

Fig. 1. Flipped classroom schematic

\subsection{Theoretical foundation}

Humanistic learning theory: The humanistic theory concludes the learning behavior into two types, i.e. meaningful learning and meaningless learning. It appeals to learners to improve overall qualities by meaningful learning based on the mastery of basic knowledge [8].

Flipped classroom fits its idea with the humanistic theory, and believes individual growth is more meaningful while helping students realize the knowledge comprehension and mastery in the learning process, With the flipped classroom, students can stimulate their learning initiative and improve their integrative learning capabilities.

Constructivist theory : The constructivism theory focuses on the dominant position of students in pedagogical activities. Only by actively constructing and exercising the initiative of learners in the learning process can they master the knowledge as learned.

Flipped classroom absorbs major values from constructivist situation, cooperation, conversation to build pre-class learning situation. In the classroom teaching phase, the teacher guides the students to finish the instructional objectives and further construct meaningful self-learning competence and process management skills. 
Autonomic and cooperative learning theories: The autonomic learning theory believes that the learner's subjective initiative is an internal factor for learning, while teachers, teaching materials, etc., are only the external factors that support learning behavior. Only when internal factors play a full part can we make full use of external factors to achieve internal and external combination for better learning outcome. The flipped classroom is very important to improve students' self-learning capabilities both before and after class. How the independent learning competence and interest is often depends on the teaching effect [9].

Cooperative learning theory is a learning style or strategy by which several groups as the units work together to achieve the one learning objective. Cooperative learning can also improve teamwork, communication, and organization skills of the groups, and help boost their overall qualities. In the whole implementation process, flipped classroom runs through the idea of cooperative learning theory, and enhances the learner's English level in the learning process with discussion of learning difficulties and keynotes, learning experiences and the sharing of study tips.

\section{Computer Technology and Education Platform Design}

\subsection{Overview of computer technology}

B/S architecture: $\mathrm{B} / \mathrm{S}$ (browser/server) architecture enables users to access the database platform via the browse, as the computer network has been prevalent. Most of the logical operations on the $\mathrm{B} / \mathrm{S}$-based computer network platform are performed on the server side. Data access is achieved by the presentation, application and database layers, which improves system maintenance convenience and access efficiency. The $\mathrm{B} / \mathrm{S}$ architecture reduces the bar for client computers. Users can access data on the server side, provided that they have logged in the browser and the Internet. The system maintenance is only required for the server side and system database. The B/S architecture applies to current network development environment and can operate on various OSs [10].

ASP.NET: ASP.NET is a kind of design and development tools for .NET applications, and can be compatible with a variety of compiler languages. It is the Webpage editor and programming tool as WYSIWYG (What You See Is What You Get) under the .NET framework, and its code is concise, clear in logic, and reusable. The reason why the college English education platform based on the $\mathrm{B} / \mathrm{S}$ architecture and the flipped classroom uses ASP.NET is that: 1 . it allows simple development and has been mature for the design and production of the Webpage and Website; 2 it supports fast development, since the system itself has a framework and integrated controls with which developer can quickly develop WEB applications; 3 it runs fast, ASP.NETbased compiler system can quickly respond to the needs of the client [11].

SQL sever: SQL sever, as the most commonly used and reliable database software, is a relational database solution launched by Microsoft. Embedded with a wide range of programming interface tools, it uses the client/server architecture, supports WEB technology, and features scalability and simple maintenance [12]. In conceptual struc- 
ture, SQL database means to collect the information and data for classification, acquire the relationship of individual entity's attributes, and design the database with the E-R (Entity-Relation) structure. Database parameters can be represented by the fields, field types, field lengths and other attributes. The data sheet of the Education Platform Administrator is shown in Fig. 1 [13].

Table 1. Data sheet of administrator in SQL server

\begin{tabular}{|c|l|l|c|l|l|}
\hline No. & \multicolumn{1}{|c|}{ Field names } & Field Type & Empty or not & \multicolumn{1}{|c|}{ Key } & \multicolumn{1}{|c|}{ Field Description } \\
\hline 1 & Ad loginName & Varchar & N & Home key & Log Name \\
\hline 2 & Password & Varchar & N & & Password \\
\hline 3 & Real Name & Varchar & Y & & Real Name \\
\hline 4 & Dep NO & Varchar & N & Foreign Key & department \\
\hline 5 & Phone & Varchar & Y & & Contact number \\
\hline 6 & E-Mail & Varchar & Y & & Email \\
\hline 7 & QQ & Varchar & Y & & QQ \\
\hline 8 & Demo & Memo & Y & & Remark \\
\hline
\end{tabular}

\subsection{Design of college students' English education platform based on flipped classroom}

Analysis of system requirements: The system responds to pedagogical activities of the flipped classroom, therefore, the process that the system is implemented depending on the flipping classroom is mainly divided into two phases: pre-class and inclass classrooms. The system users mainly include three classes: system administrator, teachers and students. As the system requires, on the premise of meeting the requirements of curriculum activities in flipped classroom, different users in the system should be assigned with appropriate authorizations to allow them to finish the pedagogical activities in the system [14]. The main modules of the system are shown in Fig 2:

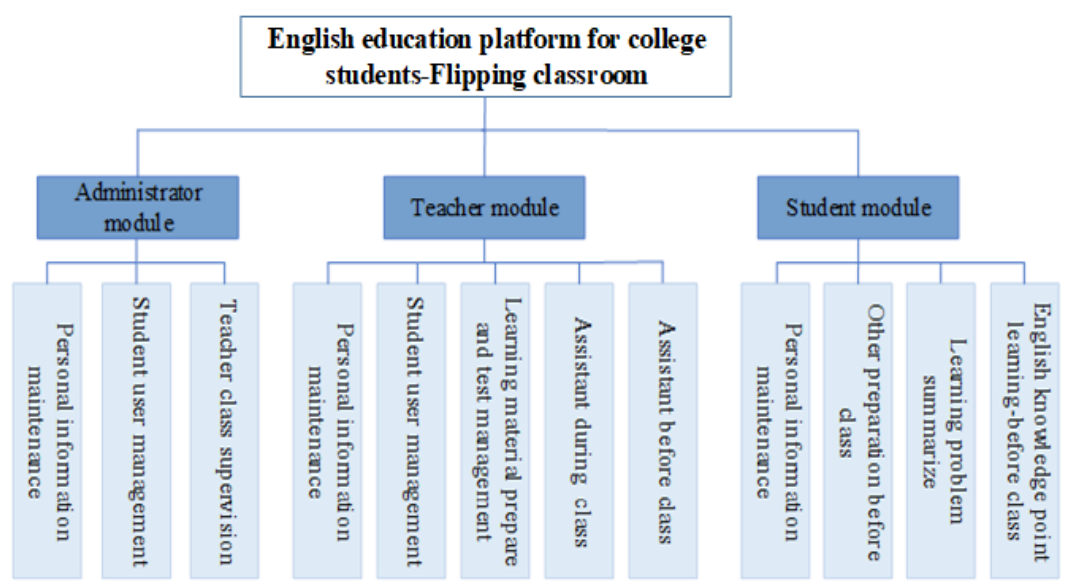

Fig. 2. The main three function module of the platform 
Design and implementation of system interface : The $\mathrm{B} / \mathrm{S}$ framework underlies the system. Users can log in URL to access the system via the browser, and perform relevant operations as different roles from the login interface. As shown in Fig 3, the administrator sets the authorization for students after logging in the appropriate interface. Before the flipped classroom starts, the administrator needs to set the authorization to let the students to access the platform. After students are authorized, they can $\log$ in the classroom network platform by the student number and spelling name.

As shown in Fig 4, these are the pre-class preparation modules of the flipped classroom. Students participating in the flipped classroom will learn in advance the main content of the next English course according to the teacher's assignment before class.

In addition, the system is designed with different user interfaces for functional requirements, as shown in Fig 2. Teachers, administrator, and students can enter different interfaces to perform appropriate operations after logging in the system. In addition to the computer Windows platform, the system is compatible with the mobile browser APP, which is convenient for the system users to operate it anytime and anywhere, especially for students to learn in a short time, so that it achieves the mobilization and simplification of English learning [15]. The system database also provides different types of links such as NetEase Open Class, U.S National English Corpus, China National Knowledge Network and abundant English learning materials as learning folders for college students. English teachers can recommend different English learning materials for students at different English levels. Diversified education is implemented in the English teaching classroom with different themes on the platform [16].

\begin{tabular}{|c|c|c|c|c|}
\hline \multicolumn{3}{|c|}{ (F) (๑) p://localhost/campus $10 \cdot \mathrm{C} \circledast$} & & \\
\hline \multicolumn{5}{|c|}{ 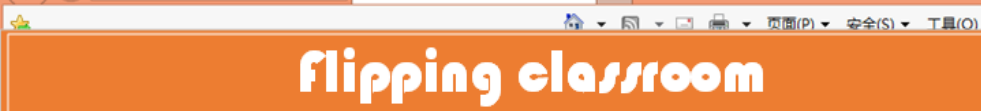 } \\
\hline \multicolumn{5}{|c|}{ Home page $\odot$ Administrator module 0 Teacher module 0} \\
\hline \multicolumn{5}{|c|}{ Student Information Management $\gg$ Student Access } \\
\hline \multicolumn{2}{|c|}{ Please enter the student name: } & Add & Query & \\
\hline User code & Name & Class & Authorised & Modify or not \\
\hline 10010 & Shenhe & 1 & $\underline{\text { Yes }}$ & Modify \\
\hline 10011 & Wugang & 2 & $\underline{\text { Yes }}$ & $\underline{\underline{M o d i f v}}$ \\
\hline 10012 & Zhaohao & 1 & $\underline{\text { Yes }}$ & $\underline{\text { Modify }}$ \\
\hline 10013 & Songjiangtao & 2 & $\underline{\text { Yes }}$ & $\underline{\text { Modify }}$ \\
\hline 10014 & Tangjiandong & 1 & $\underline{\text { Yes }}$ & $\underline{\text { Modify }}$ \\
\hline
\end{tabular}

Fig. 3. The Permission settings interface of the platform 


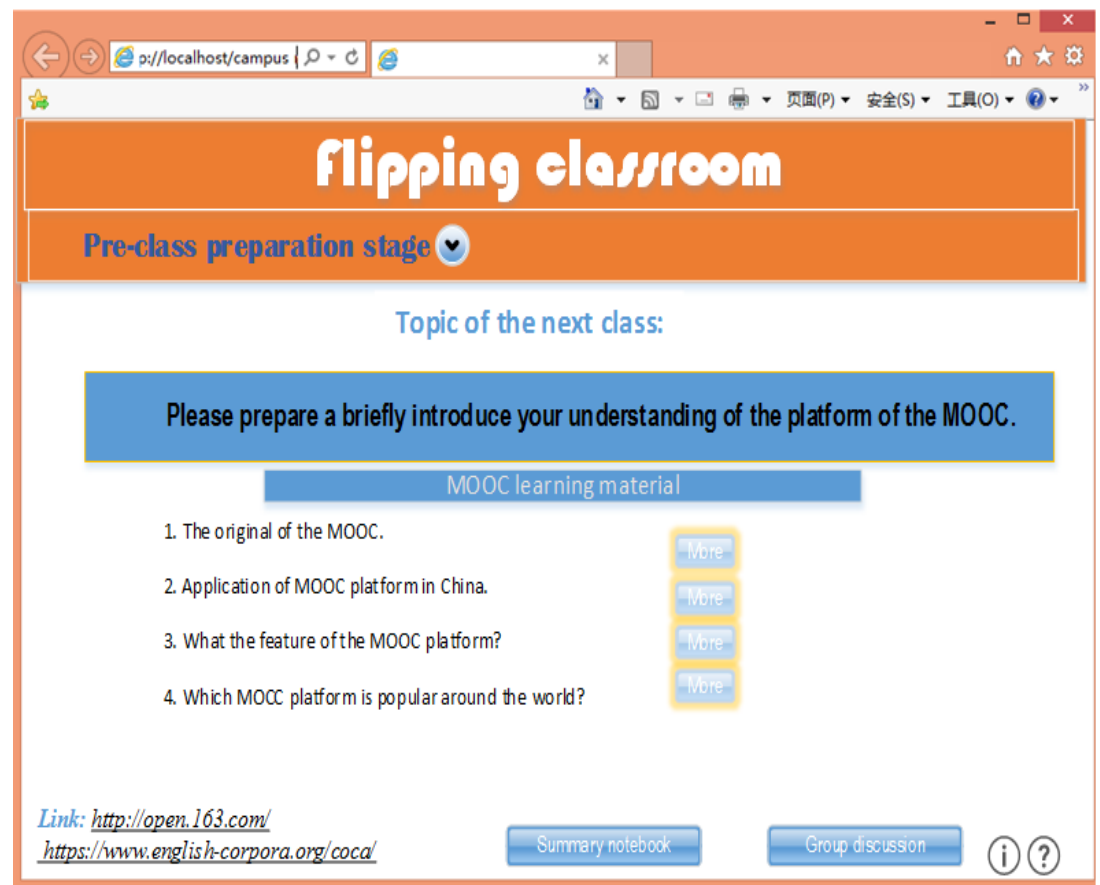

Fig. 4. The before class interface of the student after login

\section{College English Education Practice Based on B/S and Flipped Classroom}

To better demonstrate whether the flipped classroom is effective for college students' English education, this section introduces the situation of educational practice, and makes statistics on the corresponding experimental conclusions. By the interview with college students, it is concluded that the flipped classroom has several advantages for college students' English education.

\subsection{Experimental preparation}

Flipped classroom teaching experiment of half-semester computer network course is conducted with students in non-English major at the sophomore level in a university in Hunan Province as subjects. As designed, there are experimental and control classes. The former adopts the college English education model based on the B/S architecture and the flipping classroom; the traditional English teaching mode is still used in the control class. There are 45 students in two classes. The experimental test materials are available for the TOEIC comprehensive reading simulation and the listening simulation 1000 questions. The experimental class follows the teacher-based teaching 
model of flipped classroom with the $\mathrm{B} / \mathrm{S}$ architecture platform as the assistant and the control class adopts the teaching model of the traditional English classroom.

\subsection{Comparison of experimental processes and results}

Before the teaching semester starts, the experimental and control classes are tested initially for English levels. 50 questions are selected from the 1000 listening and comprehensive reading TOEIC test, each is 1 point. After teaching English for one semester, another 50 listening and 50 comprehensive reading questions are selected for the end-of-term test. According to the statistics, the average English scores of two classes are listed in Table 2.

Table 2. The experimental text result comparison

\begin{tabular}{|c|l|c|c|}
\hline \multicolumn{1}{|c|}{ Item } & \multicolumn{1}{|c|}{ Group } & Average Score & Increase Ratio \\
\hline \multirow{2}{*}{ Pre-test } & Test group & 65 & - \\
\cline { 2 - 4 } & Control group & 64 & - \\
\hline \multirow{2}{*}{ Post-test } & Test group & 76 & $16.92 \%$ \\
\cline { 2 - 4 } & Control group & 68 & $6.25 \%$ \\
\hline
\end{tabular}

After English teaching for one semester, the test scores of the two groups have changed in different degrees, but from data in the table, it is found that the English scores of the experimental group have a greater improvement than that of the control group, that is, the average score increases 65 points to 76 points, nearly by $17 \%$, while the end-of-term test score of the control group is only 68 points, an increase of only $6.25 \%$. From the individual test results, it is proved by the analysis that the flipped classroom is effective for improving the English level of college students.

\subsection{Analysis of questionnaire survey}

The purpose of flipped classroom is to improve students' interests in learning and autonomic learning capabilities. Therefore, students' subjective attitude towards flipped classroom is also the object for investigating pedagogical practices. This paper interviews 45 students in the experimental class in the form of a questionnaire survey about the following questions: 1. are you happy with the teaching model of flipped classroom? 2. are you satisfied with the arrangement of the teaching process? 3. do you adapt to the flipped classroom teaching mode? 4 . is it willing to recommend to the classmates the flipped classroom teaching model? A total of 45 copies of questionnaires were handed out and 45 valid questionnaires were collected. The statistical results are shown in Table 3. 
Table 3. Questionnaire

\begin{tabular}{|l|c|c|c|c|c|}
\hline \multicolumn{1}{|c|}{ Questions } & Totally Consent & Agree & General & Disagree & $\begin{array}{c}\text { Strongly } \\
\text { Disagree }\end{array}$ \\
\hline $\begin{array}{l}\text { If flipped classroom makes you } \\
\text { happy }\end{array}$ & $44.4 \%$ & $22.2 \%$ & $22.2 \%$ & $11.2 \%$ & 0 \\
\hline $\begin{array}{l}\text { If you are satisfy with the teaching } \\
\text { process }\end{array}$ & $55.5 \%$ & $17.7 \%$ & $15.6 \%$ & $11.2 \%$ & 0 \\
\hline $\begin{array}{l}\text { Do you adapt to the flip classroom } \\
\text { teaching mode? }\end{array}$ & $71.1 \%$ & $11.2 \%$ & $11.2 \%$ & $6.5 \%$ & 0 \\
\hline $\begin{array}{l}\text { Will you recommend flipped class- } \\
\text { room to your friend }\end{array}$ & $62.2 \%$ & $26.7 \%$ & $4.5 \%$ & $6.6 \%$ & 0 \\
\hline
\end{tabular}

According to data in the table, more than $66 \%$ of the students think that the teaching model of flipped classroom can give happiness to English learners, improve the involvement of the classroom and enhance the learning interests; $72 \%$ of the students are satisfied with the design of the teaching process. Some models including prepreparation, in-class discussion, and after-school feedback can improve the English learning level; more than $82 \%$ of the students in the experimental class can adapt to the teaching model of flipped classroom, and nearly $90 \%$ of students therein show a strong interest in a new teaching model for flipping classroom, and would like to recommend it to his friends.

In addition, the students whose scores rank top 10 in the experimental class are freely interviewed to conclude the main advantages of the flipped classroom: 1. The learning model of the test-oriented education from the primary and secondary schools is transformed, and the passive to the active learning modes, which more adapts to those students who have a high self-restraint competence; 2 . the popularity of $4 \mathrm{G}$ network and campus wireless network make various abundant materials of the flipped classroom play a part, providing basic data for college students to learn English; 3. Learning model for English knowledge points is transformed from the classroom transference into more enriched English situational learning, intriguing the interest of most students in learning English.

\section{Conclusion}

Flipped classroom as a new type of learning model has demonstrated its application effect in foreign language learning. To better guide the English education for students in China and enrich the teaching model, this paper conducts a survey under a goal of building a flipping classroom teaching platform based on $\mathrm{B} / \mathrm{S}$ architecture. Here come the study content, conclusions and prospects:

- This paper describes the concept of flipped classroom and relevant theories from the perspective of popular science, in conjunction with the computer network technology applied to it. Based on this, the English flipped classroom is designed and implemented after analyzing the system requirements. 
- It is proved experimentally in the teaching that the flipping classroom teaching platform and education model is effective, especially can regain learning interests in Chinese students' English learning and stimulate learning initiative.

- Flipped platform has been initially applied in Chinese universities, but it still needs to be developed in terms of scale and teaching coverage.

\section{References}

[1] Chen, H., Chen, H. (2015). The influence of world englishes on chineseenglish and english teaching in college. Journal of Organometallic Chemistry, 192(1): 1-15. http://dx.doi.org $\underline{10.1016 / \mathrm{S} 0022-328 \mathrm{X}(00) 93325-4}$

[2] Mcneill, A. (1996). Vocabulary knowledge profiles: evidence from chinese-speaking es1 teachers. British Journal of Radiology, 1(925): 65-7. http://dx.doi.org/10.1259/bjr/689675 $\underline{44}$

[3] Liping, C., Quanwei, W., Jiqun, W. (2014). Gw25-e0816 research and practice in electrocardiogram teaching in english mode in chinese medical undergraduate. Journal of the American College of Cardiology, 64(16): C240. https://doi.org/10.1016/j.jacc.2014.06. $\underline{1117}$

[4] Pierce, R., Fox, J. (2012). Vodcasts and active-learning exercises in a "flipped classroom" model of a renal pharmacotherapy module. American Journal of Pharmaceutical Education, 76(10): 196. http://doi.org/10.5688/ajpe7610196

[5] He, Y. (2018). Analysis of a self-learning system of English flipped classroom based on adaptive algorithm, International Journal of Emerging Technologies in Learning, 13(8): 103-116. http://doi.org/10.3991/ijet.v13i08.9056

[6] Schultz, D., Duffield, S., Rasmussen, S. C., Wageman, J. (2014). Effects of the flipped classroom model on student performance for advanced placement high school chemistry students. Journal of Chemical Education, 91(9): 1334-1339. http://doi.org/10.1021/ed4008 $\underline{68 x}$

[7] Mortensen, C. J., Nicholson, A. M. (2015). The flipped classroom stimulates greater learning and is a modern 21 st century approach to teaching today's undergraduates. Journal of Animal Science, 93(7): 3722-3731. http://doi.org/10.2527/jas.2015-9087

[8] Chen, F., Lui, A. M., Martinelli, S. M. (2017). A systematic review of the effectiveness of flipped classrooms in medical education. Medical Education, 51(6): 585-597. http://doi. org/10.1111/medu. 13272

[9] Koo, C. L., Demps, E. L., Farris, C., Bowman, J. D., Panahi, L., Boyle, P. (2016). Impact of flipped classroom design on student performance and perceptions in a pharmacotherapy course. American Journal of Pharmaceutical Education, 80(2): 33. http://doi.org/10.56 88/ajpe80233

[10] Lopes, C. T., Franz, M., Kazi, F., Donaldson, S. L., Morris, Q., Bader, G. D. (2010). Cytoscape web: an interactive web-based network browser. Bioinformatics, 26(18): 2347-2348. http://doi.org/10.1093/bioinformatics/btq430

[11] Khatri, P., Bhavsar, P., Bawa, G., Draghici, S. (2004). Onto-tools: an ensemble of webaccessible, ontology-based tools for the functional design and interpretation of highthroughput gene expression experiments. Nucleic Acids Research, 32(Web Server): W449W456. http://doi.org/10.1093/nar/gkh409

[12] Stonebraker, M. (2010). Sql databases v. nosql databases. Communications of the ACM, 53(4): 10. http://doi.org/10.1145/1721654.171659 
[13] Libkin, L. (2003). Expressive power of sql. Theoretical Computer Science, 296(3): 379404. http://doi.org/10.1016/s0304-3975(02)00736-3

[14] White, P. J., Naidu, S., Yuriev, E., Short, J. L., Larson, I. C. (2017). Student engagement with a flipped classroom teaching design affects pharmacology examination performance in a manner dependent on question type. American journal of pharmaceutical education, 81(9): 5931. http://doi.org/10.5688/ajpe5931

[15] Rau, M. A., Kennedy, K., Oxtoby, L., Bollom, M., Moore, J. W. (2017). Unpacking “active learning": a combination of flipped classroom and collaboration support is more effective but collaboration support alone is not. Journal of Chemical Education, 94(10): 14061414. http://doi.org/10.1021/acs.jchemed.7b00240

[16] Mita, Y., Kawahara, Y. (2017). 15-year educational experience on autonomous electronic information devices by flipped classroom and try-by-yourself methods. IET Circuits, Devices \& Systems, 11(4): 321-329. http://dx.doi.org/10.1049/iet-cds.2016.0406

\section{$7 \quad$ Authors}

Yuanbo Li, male, was born on July 25, 1980, with a Master's degree, major in English Language and Literature. He is currently working as an English teacher at Hebei vocational College for Railway Transportation in Shijiazhuang, China. He has been teaching English courses for 14 years, including College English course and Listening \& Speaking course. Currently, He is serving as Director of English Teaching and Research. He has published two books and several papers on English teaching. In 2013, he is excellent in annual assessment. In 2015, he was rated as an excellent educator of Hebei vocational College for Railway Transportation.

Chenhui Qu, female, was born on August 1, 1979, with a bachelor's degree. She is currently working as an English teacher at Hebei vocational College for Railway Transportation, China. In 2013, she was awarded the third-level talent in the new century. In 2015, she is excellent in annual assessment. In 2017, she was rated as an excellent educator of Hebei Rail Transit Vocational and Technical College. In 2018, the college's target performance appraisal was excellent. In the same year, "International Exchange and Cooperation Research and Reference" was published in the provincial publication. In Human Resources, in March 2019, the subject of research and reference for the international exchange and cooperation of the People's Office of Hebei Province was successfully concluded and won the first prize.

Article submitted 2019-05-27. Resubmitted 2019-07-05. Final acceptance 2019-07-05. Final version published as submitted by the authors. 